\title{
ObSERVATION OF A BLUe Whale (BALAENoptera MUSCULUS) FEEDING IN COASTAL WATERS OF ECUADOR
}

\author{
Fernando FÉlix ${ }^{1,2, *}$, Natalia Botero ${ }^{1,3}$ AND Jéssica Falconi ${ }^{1,4}$
}

\begin{abstract}
Aвstract: The presence of the blue whale (Balaenoptera musculus) in continental waters of Ecuador is known from only a few reports. Here we present photographic evidence of a blue whale feeding in costal waters of this country. The event occurred on 17 July 2007, 2nm west of Salinas, Santa Elena Peninsula $\left(2^{\circ} 12^{\prime} 08^{\prime \prime}\right.$ S, $\left.81^{\circ} 02^{\prime} 31^{\prime \prime W}\right)$. The whale was followed during 31 minutes aboard a whalewatching boat. At one point, the whale was observed moving fast at the surface and rolling over its right side with its mouth open. Although the type of food being consumed was not evident, the behavior is similar to that described as surface feeding on euphausiid swarms. Despite the intense whale research effort conducted over the past 15 years in coastal waters of Ecuador, this is the first time a blue whale is recorded in nearshore waters.
\end{abstract}

RESUMEN: La presencia de ballenas azules Balaenoptera musculus en aguas continentales de Ecuador es solamente conocida por unos pocos registros. En este artículo presentamos evidencia fotográfica del avistamiento de una ballena azul alimentándose en aguas costeras de Ecuador. El suceso ocurrió el 17 de julio de 2007, apenas a $2 \mathrm{mn}$ al oeste de Salinas, península de Santa Elena $\left(2^{\circ} 12^{\prime} 08^{\prime \prime} \mathrm{S}, 81^{\circ} 02^{\prime} 31^{\prime \prime} \mathrm{W}\right)$. La ballena fue seguida por 31 minutos a bordo de un yate de turismo utilizado regularmente como plataforma de investigación. En un momento dado, la ballena fue observada nadando rápido en la superficie y girando sobre su lado derecho con la boca abierta. Aunque no se observó que tipo de alimento ingería, este comportamiento ha sido descrito como una forma de alimentación de las ballenas azules sobre enjambres de eufáusidos que se concentran en la superficie. Pese al intenso esfuerzo de investigación de ballenas desarrollado en los últimos 15 años en aguas costeras de Ecuador, ballenas azules no habían sido registradas hasta ahora.

KEYwords: Blue whale, Balaenoptera musculus, feeding, distribution, Ecuador

\section{Introduction}

The blue whale (Balaenoptera musculus) is a cosmopolitan species that is distributed mainly along shelf margins and to a lesser extent in oceanic waters and coastal zones (Leatherwood and Reeves, 1983). In contrast to most balaenopterids that undergo long annual migrations between the feeding grounds in polar zones and the breeding areas in tropical waters, the movements and migration patterns of blue whales are less well known and seem to be more complex than in species such as humpback (Megaptera novaeangliae) or fin whales (Balaenoptera physalus) (Perry et al., 1999; Branch et al., 2007).

In the eastern tropical Pacific, blue whales occur mainly in upwelling areas characterized by waters of cool temperature and high primary productivity such as Baja California, the Costa Rica Dome, the Galápagos Islands, and off southern Ecuador and northern Peru (Reilly and Thayer, 1990). High concentrations of euphausiids or "krill" is a common characteristic to these areas, and is why it has been suggested that the presence of blue whales in these areas could be related to feeding activities (Reilly and Thayer, 1990; Gendron and Sears, 19935; Fiedler et al., 1998; Palacios, 1999; Ballance et al., 2006; Branch et al., 2007).
Blue whales occur regularly along most of the South American Pacific coast, as indicated by catches reported from Peru and Chile during the $20^{\text {th }}$ century (see Clarke, 1980). The occurrence of the species during all months of the year off Peru (Ramírez, 1983) suggests the presence of whales from both hemispheres in their respective winter and spring months, although it has also been suggested that a discrete sub-stock could inhabit this part of the Eastern Pacific year round (Donovan, 1984; Branch et al., 2007). In contrast to other countries of the Southeast Pacific, records of blue whale in Ecuador are scarce; most of them have been made in the Galápagos Islands $(1,000 \mathrm{~km}$ west of Ecuador), particularly along the west side where upwelling is strong (e.g. Reilly and Thayer, 1990; Wade and Gerrodette, 1993; Merlen, 1995; Palacios, 1999). The number of records from Galápagos, however, indicates that the species is currently not abundant there. Since records have been made almost exclusively during the austral winter and spring months, these whales would correspond to a Southern Hemisphere population (Reilly and Thayer, 1990; Palacios, 1999). The presence of blue whales in continental waters of Ecuador is even less well known. Clarke (1962) reported on a whaling expedition in coastal waters of Ecuador in 1926 whose catches mainly included young blue and fin whales. In addition to the few sightings reported by Reilly and Thayer (1990) off southern Ecuador and north of Peru

\footnotetext{
${ }^{1}$ Fundación Ecuatoriana para el Estudio de Mamíferos Marinos (FEMM). PO Box 09-01-11905. Guayaquil, Ecuador.

${ }^{2}$ Pontificia Universidad Católica del Ecuador (PUCE). Av. 12 de Octubre and Patria, Quito, Ecuador.

${ }^{3}$ Universidad de Antioquia. Calle 67 No $53 \cdot 108$, Medellín, Colombia.

${ }^{4}$ Universidad Estatal Península de Santa Elena (UPSE). Vía La Libertad-Santa Elena, La Libertad, Ecuador.

* Corresponding author, e-mail: fernandofelix@femm.org.

${ }^{5}$ Gendron, D. and Sears, R. (1993) Blue whale and Nyctiphanes simplex surface swarms: a close relationship in the southwest Gulf of California,

Mexico. Page 52 in Abstracts, X Biennial Conference on the Biology of Marine Mammals, 11-15 November, Galveston, TX, USA.
} 
between 1974 and 1988 (in fact all of them were recorded off Peru, south of $4^{\circ} \mathrm{S}$ ), there is only one additional sighting in southern Ecuador, made in 1999 $\left(3^{\circ} \mathrm{S}, 83^{\circ} \mathrm{W}\right)$ during a marine mammal survey carried out by a ship from the National Oceanic and Atmospheric Administration (NOAA) of the United States (Kinzey et al., 2000).

In this article we report on the sighting of a blue whale in coastal waters of Ecuador. In addition to being one of the few sightings of this species in Ecuadorian waters, the most relevant aspect is that the animal was engaged in behavior consistent with feeding activity.

\section{The record}

On 17 July 2007, aboard of a whalewatching yacht used regularly by Fundación Ecuatoriana para el Estudio de Mamíferos Marinos researchers as platform to study humpback whales off Salinas, Ecuador, a blue whale was recorded $2 \mathrm{~nm}$ west of the Santa Elena Peninsula $\left(2^{\circ} 12^{\prime} 08^{\prime \prime S}, 81^{\circ} 02^{\prime} 31^{\prime \prime} \mathrm{W}\right.$; Figure 1$)$. The tip of the peninsula is the westernmost part of Ecuador and extends $12 \mathrm{~km}$ into the Pacific Ocean, further restricting the already narrow continental shelf along this part of the coast (de Miro et al., 1976). According to the Navigation Chart I.O.A. $105^{6}$ the depth of the sighting location was $\sim 50 \mathrm{~m}$.

The individual was followed for 29 minutes from 11:41h to $12: 10 \mathrm{~h}$. The track during the sighting period shows that the whale moved $1.8 \mathrm{~km}$ in a southerly direction at an average speed of $3.72 \mathrm{~km} / \mathrm{h}$, assuming a straight line movement. On several occasions the animal was close enough to be photographed and positively identified to species. Dives lasted at least 5 minutes, after which the animal took three breaths at the surface. As it came up to breathe, the whale exposed the anterior and mid upper part of its grayish back, and on a few occasions

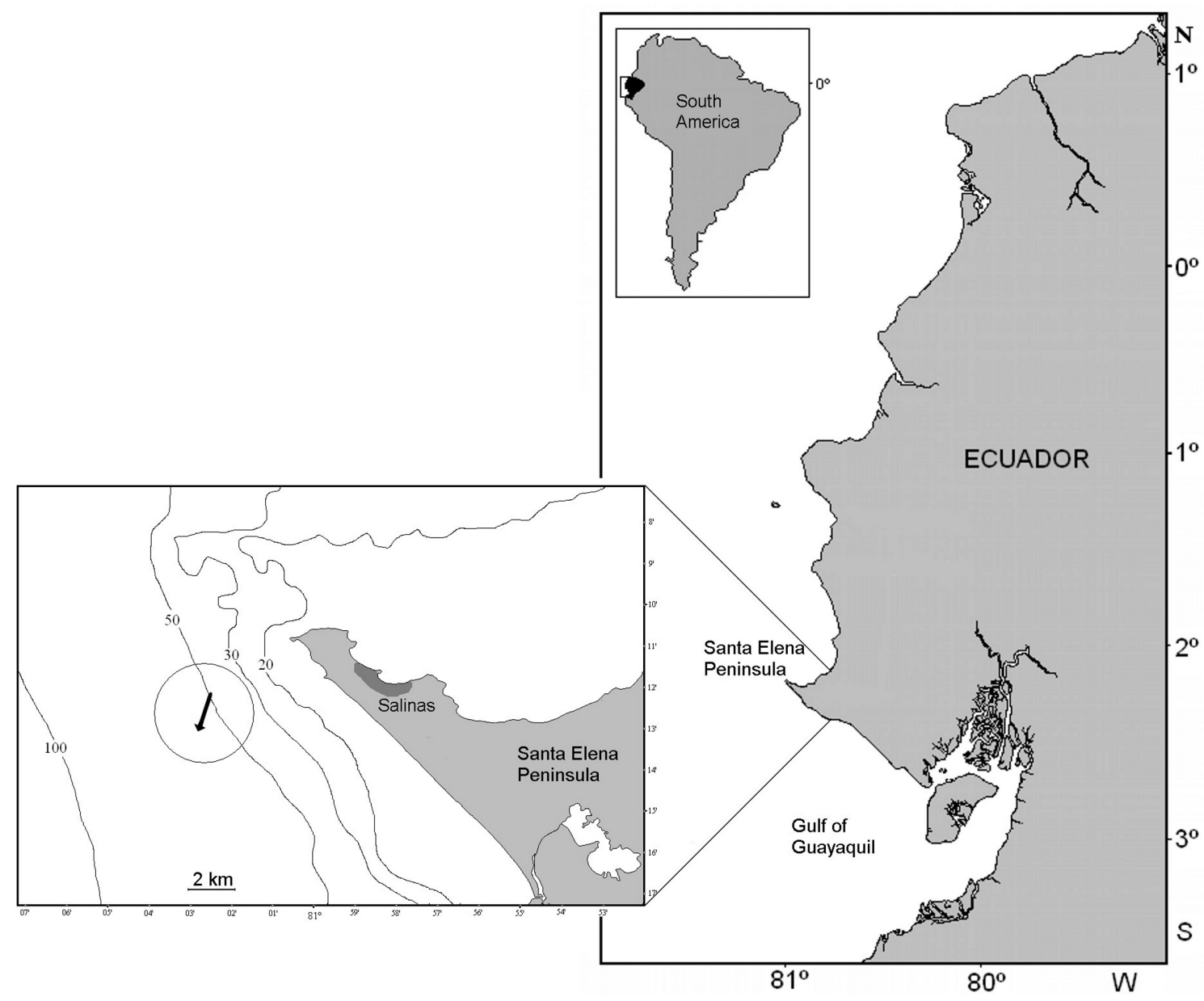

Figure 1. Sighting site off the Santa Elena Peninsula, Ecuador. The arrow in the circle (left) indicates the direction and the distance traveled by the whale during the observation period.

${ }^{6}$ The chart is produced by the Oceanographic Institute of the Ecuadorian Navy (INOCAR). 
the dorsal fin, which was low and falcate, located well behind in the lower back (Figure 2). At one point, the animal made sudden fast movements at the surface and rolled over its right side with its mouth open, partially exposing the ventral groves and part of the left row of black-colored baleen plates (Figure 3). The left flipper and part of the flukes were also visible above the surface at this time.

\section{Discussion}

Despite the intense whale research effort in coastal waters of Ecuador during the past 15 years, with three research teams studying humpback whales in several sites of the central and northern coast during the austral winter (June-September) (see Félix and Haase, 2001, 2005; Castro and González, 2002; Félix et al., in press), no blue whales have been reported previously in this area. Therefore, while our report could be considered extraordinary, blue whales are known to occur along shelf margins, so it is not ruled out that they may be more abundant offshore. Unfortunately, it is not possible to say much about their offshore occurrence because, in addition to the marine mammal surveys by NOAA in the eastern tropical Pacific, only a few expeditions to study whales have been conducted in offshore waters (e.g. Clarke, 1962; Loech, 1966; Chiriboga, 1972; Clarke et al., 2002), all of which have failed to find blue whales.

The whale's behavior of rolling at the surface with its mouth open is similar to that described previously elsewhere and referred to as a form of surface feeding on euphausiid swarms (e.g. Fiedler et al., 1998; Palacios, 1999), but such swarms were not evident during the sighting period nor have they been reported in coastal waters of Ecuador. The largest volumes of both microand macro-zooplankton off mainland Ecuador have been associated with the Equatorial Front (2-3 5 ), where cold northbound waters from the Humboldt Current meet the warm southbound waters of the Panama Current, and where primary productivity can be as high as $760 \mathrm{mgC} / \mathrm{m}^{3} / \mathrm{d}$ (Jiménez and Pesantes, 1978; Jiménez, 1996). At the regional level, however, the productivity along the coast of Ecuador is not comparable to the levels found in the upwelling zones

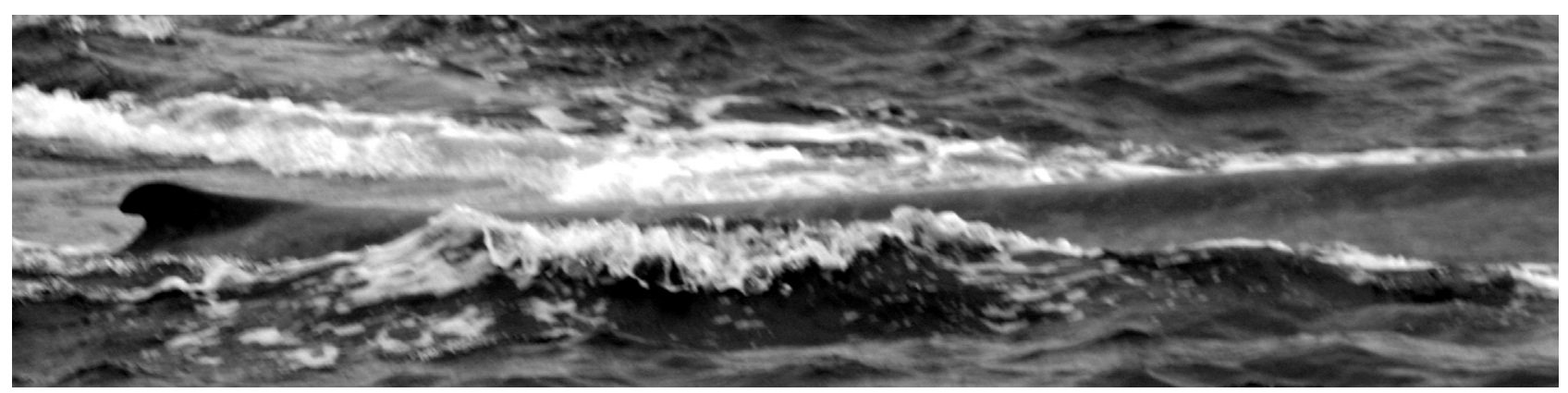

Figure 2. Rear upper dorsum and dorsal fin of the whale sighted off Santa Elena Peninsula, Ecuador.

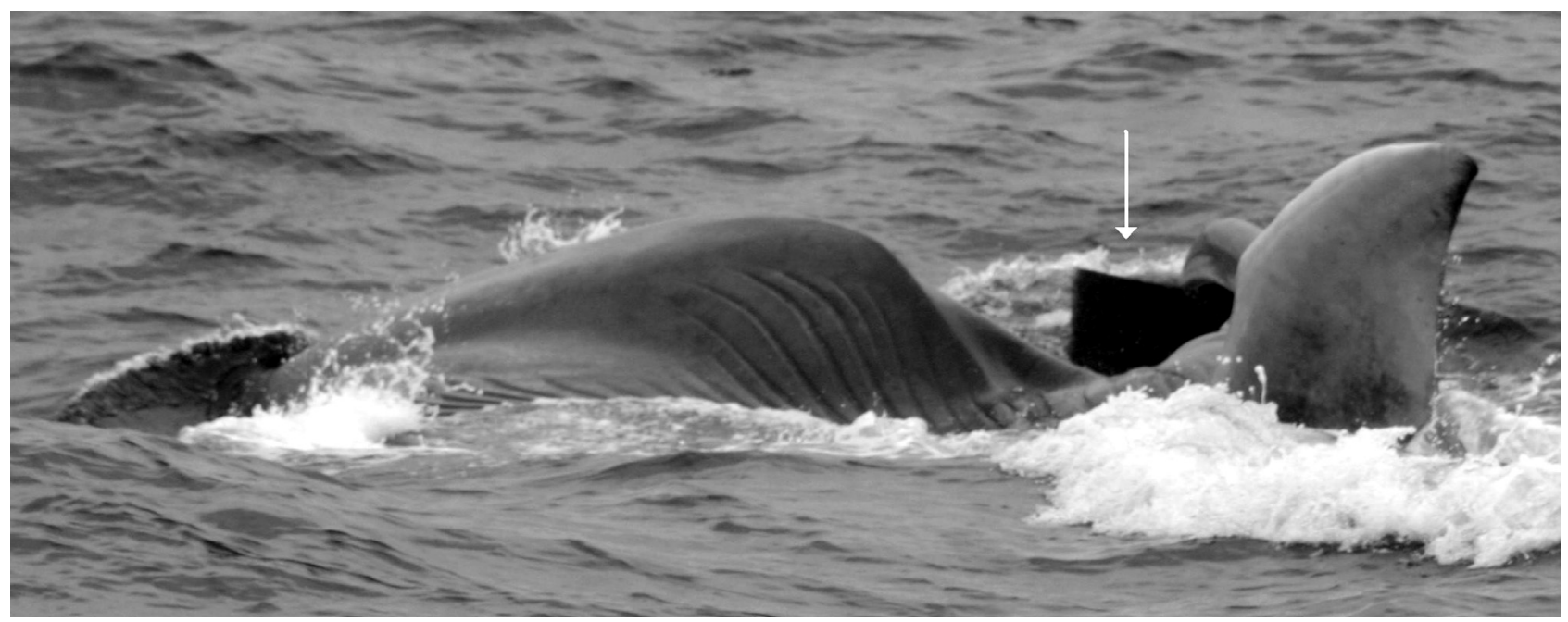

Figure 3. Behavior shown by the whale at the surface in waters off Santa Elena Peninsula, Ecuador. Note the open mouth and the left row of baleen plates (arrow) to the left of the pectoral fin. 
along the coasts of Peru and Chile (see Brown et al., 2005), sites that traditionally are known for the presence of blue whales in the Southeast Pacific (Aguayo, 1974; Clarke, 1980; Ramírez, 1983).

Since our record was made during the austral winter, it could be inferred that this individual belonged to a Southern Hemisphere population, likely to the same population found in Peruvian waters. However, from the data of blue whale abundance off Peru provided by Ramírez (1983), it is noticed that the whales peaked in austral summer (between January and February), with a minimum during the winter months; that is, the time when we recorded the whale in Ecuador. Recently, Branch et al. (2007) have provided new evidence to support the hypothesis of a discrete subpopulation carrying out seasonal migrations within the Southeast Pacific, with animals moving from the south of Chile to the coast of Peru, Ecuador and the Galápagos Islands during the summer, although with some whales remaining in both zones during the entire year. The current state of knowledge indicates that blue whales from the Southeast Pacific would be a different subpopulation from both pygmy and Antarctic blue whales, with their own genetic, acoustic and morphologic characteristics (Branch et al., 2007).

Genetic studies and the use of photo-identification would help to establish the identity of blue whales inhabiting Ecuadorian waters, their relationship to blue whales recorded in other areas of the Southeast Pacific such as Galápagos (Palacios, 1999), Chile (e.g. HuckeGaete et al., 2004; Galletti et al., 2007), and Peru (Ramírez, 1983), thus improving our knowledge of the dynamics and structure of the stock.

\section{Acknowledgements}

The authors thank the tourism agency Pesca Tour, owners of the yacht "China Linda", aboard of which we made the sighting. A special thanks to the yacht's crew for their patience and for taking us aboard during the time we have been working in Salinas. Daniel Palacios, Diane Gendron and an anonymous reviewer made valuable comments to improve the manuscript.

\section{References}

Aguayo, A. (1974) Baleen whales off continental Chile. Pages 209-217 in Schevill, W.E. (Ed.) The Whale Problem. Harvard University Press, Cambridge, MA, USA. 419pp.

Ballance, L.T., Pitman, R.L. and Fiedler, P.C. (2006) Oceanographic influences on seabirds and cetaceans of the eastern tropical Pacific: a review. Progress in Oceanography 69: 360-390.

Branch, T.A., Stafford, K.M., Palacios, D.M., Allison, C., Bannister, J.L., Burton, C.L.K., Cabrera, E., Carlson, C.A., Galletti Vernazzani, B., Gill, P.C., Hucke-Gaete, R., Jenner, K.C.S., Jenner, M.-N.M., Matsuka, K., Mikhalev, Y.A.,
Miyashita, T., Morrice, M.G., Nishiwaki, S., Sturrock, V.J., Tormosov, D., ANDERson, R.C., BAKer, A.N., Best, P.B., BORSA, P., Brownell JR, R.L., Childerhouse, S., Findlay, K.P., Gerrodette, T., Ilangkoon, A.D., Joergensen, M., Kahn, B., Ljungblad, D.K., Maughan, B., Mccauley, R.D., Mckay, S., Norris, T.F., Oman Whale and Dolphin Research Group, Rankin, S., Samaran, F., Thiele, D., Van Waerebeek, K. and WARNEKE, R.M. (2007) Past and present distribution, densities and movements of blue whales Balaenoptera musculus in the Southern Hemisphere and northern Indian Ocean. Mammal Review 37(2): 116-175.

Brown, M., Ortiz, J., Pinto, E., de la Cuadra, T., Zambrano, E., Flores, R., Grados, C., Pizarro, L. and Munaylla, U. (2005) Séptimo crucero regional conjunto de investigación oceanográfica en el Pacífico Sudeste, realizado en septiembreoctubre de 2004. Comisión Permanente del Pacífico Sur. Guayaquil, Ecuador. 48 pp.

Castro C. and González, J. (2002) Población de la Ballena Jorobada Megaptera novaeangliae en el Parque Nacional Machalilla, Ecuador. Ph.D. Thesis. Universidad Central del Ecuador. Quito, Ecuador. 130 pp.

Chiriboga, H.A. (1972) Las Ballenas en el Pacífico Sur Oriental. Instituto Oceanográfico de la Armada del Ecuador, Salinas, Ecuador. 54 pp.

ClaRKe, R. (1962) Whale observation and whale marking off the coast of Chile in 1958 and from Ecuador and beyond the Galapagos Islands in 1959. Hvalfangst Tidente 7: 265-287.

Clarke, R. (1980) Catches of sperm whales and whalebone whales in the southeast Pacific between 1908 and 1975. Report of the International Whaling Commission 30: 285-288.

Clarke, R, Félix, F., Paliza, O. and Brtnik P. (2002) Ballenas y delfines observados por la expedición Ballenas Libres durante el crucero oceanográfico CO-II-01 entre Guayaquil y las Islas Galápagos del 17 de septiembre al 9 de octubre de 2001. Acta Oceanográfica del Pacífico, Instituto Oceanográfico de la Armada del Ecuador (INOCAR), Ecuador 11(1): 173-180.

De Miro, M., Ayón, H. And Benites, S. (1976) Morfología y estructura del margen continental del Ecuador. Instituto Oceanográfico de la Armada del Ecuador (INOCAR). Guayaquil, Ecuador. 22 pp.

Donovan, G.P. (1984) Blue whales off Peru, December 1982, with special reference to pygmy blue whales. Report of the International Whaling Commission 34: 473-476.

FÉlix, F. AND HAASE, B. (2001) The humpback whale off the coast of Ecuador, population parameters and behavior. Revista de Biología Marina y Oceanografía 36(1): 61-74.

FÉLIX, F. AND HAASE, B. (2005) Distribution of humpback whales along the coast of Ecuador and management implications. Journal of Cetacean Research and Management 7(1): 21-31.

Félix, F., Castro, C., Laake, J., Haase B. and Scheidat, M. (In press) Abundance and survival estimates of the Southeastern Pacific humpback whale stock from 1991-2006 photoidentification surveys in Ecuador. Journal of Cetacean Research and Management (special issue).

Fiedler, P.C., Reilly, S.B., Hewitt, R.P. Demer, D., Philbrick, A., Smith, S., Armstrong, W., Croll, D.A., Tershy, B.R. And MAтE, B.R. (1998) Blue whale habitat and prey in the California Channel Islands. Deep-Sea Research II 45: 1781-1801. 
Galletti, B., Carlson, C.A., Cabrera, E. and Brownell Jr. R.L. (2007) Status of blue whales off isla de Chiloe, Chile, during 2007 field season. Document SC/59/SH1. Presented to the $59^{\text {th }}$ Scientific Committee of the International Whaling Commission, Anchorage, USA, 7-18 May 2007.

Hucke-Gaete, R., Osman L.P., Moreno, C.A., Findlay, K.P. and LJUNGBLAD, D.K. (2003) Discovery of a blue whale feeding and nursing ground in southern Chile. Proceedings of the Royal Society of London B (Supplement) 271: 170-173.

Jiménez, R. (1996) Segunda Parte: biología, ecología y acuacultura. Pages 117-223 in Comisión Asesora Ambiental de la Presidencia de la República (CAAM). Sistemas Biofísicos en el Golfo de Guayaquil. Guayaquil, Ecuador. 223 pp.

JiméneZ, R. AND Pesantes, F. (1978) Fitoplancton, producción primaria y pigmentos en aguas costeras ecuatorianas. Publicación Instituto Oceanográfico de la Armada del Ecuador (INOCAR) 2(1): 1-30.

Kinzey, D., Gerrodette, T., Barlow, J., Dizon, A., Perryman, W. AND Olson, P. (2000) Marine mammal data collected during a survey in the eastern tropical Pacific Ocean aboard the NOAA ships "McArthur" and "David Starr Jordan", July 28-December 9, 1999. NOAA Technical Memorandum NOAA-TM-NMFSSWFC 293: 1-89.

Leatherwood, S. and Reeves, R.R. (1983) The Sierra Club Handbook of Whales and Dolphins. Sierra Club Books. San
Francisco, CA, USA. 302 pp.

Loesch, H. (1966) Observación de ballenas en aguas ecuatorianas. Informe de datos, mayo de 1963 y enero-febrero de 1964. Boletín Científico y Técnico 1: 1-18.

Merlen, G. (1995) A Field Guide to the Marine Mammals of Galapagos. Instituto Nacional de Pesca, Guayaquil, Ecuador. $130 \mathrm{pp}$.

Palacios, D.M. (1999) Blue whale (Balaenoptera musculus) occurrence off the Galápagos Islands, 1978-1995. Journal of Cetacean Research and Management 1(1): 41-51.

Perry, S.C., De Master, D.P. AND Silber, G.K. (1999) The great whales history and status of six species listed as endangered under the US Endangered Species Act of 1972. Marine Fisheries Review (special issue) 61(1): 1-74.

RAmírez P. (1983) Capturas y observaciones de la ballena azul Balaenoptera musculus, L, en Paita-Perú 1961-1966 y 1975-1982 IMARPE. Revista de la Comisión Permanente del. Pacífico Sur 13: 97-102.

ReIlly, S.B. AND Thayer, V.C. (1990) Blue whale (Balaenoptera musculus) distribution in the Eastern Tropical Pacific. Marine Mammal Science 6(4): 265-277.

Wade P.R., And Gerrodette, T. (1993) Estimates of cetacean abundance and distribution in the eastern tropical Pacific. Report of the International Whaling Commission 43: 477-493. 
